\title{
Screening of Ginger Genotypes for Shoot Borer (Conogethes punctiferalis Guen.) Resistance under Soppinabetta Ecosystem of Karnataka, India
}

\author{
Y. Ravi ${ }^{1,4 *}$, V.B. Narayanpur ${ }^{1}$, J. Jayappa ${ }^{1}$, A. Prashant ${ }^{1}$, G.R. Santosha ${ }^{1}$, \\ P.S. Mahantesh ${ }^{1}$, N.M. Kotur ${ }^{2}$ and M. Avinash ${ }^{3}$ \\ ${ }^{1}$ University of Horticultural Sciences, Bagalkot-587104, Karnataka, India \\ ${ }^{2}$ Dr. YSR Horticulture University, Venkataramannagudem-534101, Andhra Pradesh, India \\ ${ }^{3}$ Kerala Agriculture University, Thrissur-680651, Kerala, India \\ ${ }^{4}$ ICAR-National Research Centre on Seed Spices, Ajmer-305206, Rajasthan, India
}

*Corresponding author

A B S T R A C T

\begin{tabular}{|l|}
\hline Ke y w or d s \\
$\begin{array}{l}\text { Ginger, genotypes, shoot } \\
\text { borer, screening, } \\
\text { resistance }\end{array}$ \\
\hline Article Info \\
\hline $\begin{array}{l}\text { Accepted: } \\
12 \text { April } 2018 \\
\text { Available Online: } \\
10 \text { May } 2018\end{array}$ \\
\hline
\end{tabular}

\section{Introduction}

Ginger (Zingiber officinale Rosc.) is an important spice and medicinal crop, is mainly grown in Nigeria, India, China, Indonesia, Thailand and Nepal. In India, it is grown in an area of $1,65,000$ hectares with an annual production of 10,81,000 MT with productivity of 6.57 MT per hectare (Anon., 2017). More than 30 species of insects have been reported to infest the crop in India including under storage, among which, shoot borer (Conogethes punctiferalis Guen.) (Pyralidae: Lepidoptera) is the most serious pest
(Devasahayam and Koya, 2004). Adult moth lays eggs on the tender unopened leaf and the larvae on hatching scrape and feed on the green contents of the leaf; later they bore into the shoots and feed on the inner core, resulting in withered shoots. The yield of the crop is significantly affected when more than $45 \%$ of the shoots in a clump are damaged by the pest (Koya et al., 1986). Intensive use of pesticides in the field for the management of the pest could result in pesticide residues in the produce, and may also cause harm to the ecosystem. Host resistance is one of the component in any disease management 
programme. It is the most economical and safest method for disease management. Hence, development of resistant varieties and their incorporation in IPM schedules is a viable alternative for management of this pest. Keeping the above in view, the collected ginger genotypes were screened for their resistance/susceptibility to the shoot borer.

\section{Materials and Methods}

Screening of 16 ginger genotypes including popular cultivars and high yielding varieties against the shoot borer was carried out during 2014-15 at the farm field of the division of Plantation, Spices, Medicinal and Aromatic Crops, College of Horticulture, Sirsi, Karnataka $\left(14.26^{\circ} \mathrm{N}\right.$ and $74.5^{\circ} \mathrm{E}, 619$ meters above MSL, mean annual rainfall $2353 \mathrm{~mm}$ ).

The Rhizomes (20-25 g size) of each genotype were planted in raised bed of $3.00 \mathrm{~m}$ length, $1.0 \mathrm{~m}$ width and $15 \mathrm{~cm}$ height at a spacing of $30 \mathrm{~cm} \times 20 \mathrm{~cm}$. and replicated twice. All agronomic practices were followed as per the package of practice recommended by UHS, Bagalkot (Anon., 2013).

The number of damaged (dead hearts/shoots with the characteristic bore hole) and healthy shoots were recorded in each genotype when the symptoms of pest damage reached its peak. Scoring of pest incidence (shoot borer) was done at 90, 120 and 150 days after planting and calculated by using this formula.

Pest incidence $(\%)=\frac{\text { Total number of affected plants }}{\text { Total number of plants }} \times 100$

\section{Results and Discussion}

The rating of different ginger genotypes to the shoot borer at 90, 120 and 150 days after planting indicated that, the genotypes like Humanabad Local $(7.35 \%, 8.88 \%$ and $10.00 \%$ incidence), Bidar-2 (10.00\%, $11.00 \%$ and
$12.88 \%$ incidence) and Rio-de-Janeiro $(9.50 \%, 11.55 \%$ and $13.85 \%$ incidence) found tolerant to the incidence of Shoot borer. Whereas the genotype IISR- Varada is susceptible to shoot borer and recorded significantly higher incidence $(19.35 \%$, $20.26 \%$ and $21.76 \%$ incidence) which was on par with Suravi $(17.30 \%, 18.75 \%$ and $19.38 \%$ incidence). These results are comparable with minimum shoot borer incidence reported at IISR Kerala, with $21.8 \%$ incidence was reported in the genotype IISR- Varada (Devasahayam et al., 2010 and Senapati and Ghose, 2005).

The study indicated that none of the ginger genotypes screened was highly resistant to the shoot borer; however, all the genotypes were susceptible to the pest attack. Whereas, four genotypes were rated as moderately resistant ( $0.1 \%$ to $12.5 \%$ range of shoot damage), seven genotypes were rated as moderately susceptible $(12.6 \%$ to $17.1 \%$ range of shoot damage), five genotypes were rated as susceptible (17.2\% to $21.8 \%$ range of shoot damage) and none of the genotypes were rated as highly susceptible to the pest. Since the variation in the per cent shoot damage between various genotypes was wide.

The mean and standard deviation of the maximum shoot damage was used for fixing various categories of resistance/susceptibility. The categorization based on the extent of variation from the mean (positive or negative) reduced the probabilities of inclusion of pseudo resistant susceptible genotypes (Bhumanavar et al., 1989).

The four genotypes which exhibited a moderately resistant reaction in the present study provides the breeders with a wide choice of breeding lines for developing ginger varieties resistant to the shoot borer. Further these genotypes can be used for cultivation under shoot borer prone areas (Table 1 and 2). 
Table.1 Reaction of different ginger genotypes to shoot borer (Conogethes punctiferalis Guen) incidence

\begin{tabular}{|l|c|c|}
\hline \multicolumn{1}{|c|}{ Category of resistance } & Range of shoot damage (\%) & Number of genotypes \\
\hline Highly resistant & 0 & Nil \\
\hline Moderately resistant & $0.1-12.5$ & 4 \\
\hline Moderately susceptible & $12.6-17.1$ & 7 \\
\hline Susceptible & $17.2-21.8$ & 5 \\
\hline Highly susceptible & $>21.8$ & Nil \\
\hline
\end{tabular}

Table.2 Shoot borer incidence indifferent ginger genotypes under Soppinabetta ecosystem of Karnataka

\begin{tabular}{|c|l|c|c|c|}
\hline \multirow{2}{*}{ Sl. No. } & \multicolumn{1}{|c|}{ Genotypes } & \multicolumn{3}{|c|}{ Shoot borer incidence (\%) } \\
\cline { 3 - 5 } & & 90 DAP & $\mathbf{1 2 0}$ DAP & 150 DAP \\
\hline 1 & Suprabha & 14.88 & 17.73 & 19.39 \\
\hline 2 & IISR-Mahima & 14.75 & 16.28 & 18.50 \\
\hline 3 & Karkala Local & 11.30 & 12.90 & 14.73 \\
\hline 4 & Humnabad Local & 7.35 & 8.88 & 10.00 \\
\hline 5 & Himagiri & 15.00 & 17.73 & 20.00 \\
\hline 6 & IISR-Varada & 19.35 & 20.26 & 21.76 \\
\hline 7 & Suravi & 17.30 & 18.75 & 19.38 \\
\hline 8 & Shikaripura Local & 13.63 & 15.23 & 16.63 \\
\hline 9 & Suruchi & 13.13 & 16.89 & 19.23 \\
\hline 10 & Jorhat-1 & 11.00 & 13.28 & 16.85 \\
\hline 11 & Himachal & 12.50 & 14.33 & 17.85 \\
\hline 12 & Rio-de-Janeiro & 9.50 & 11.55 & 13.85 \\
\hline 13 & IISR-Rajatha & 14.00 & 16.73 & 17.88 \\
\hline 14 & Bidar-1 & 10.50 & 11.23 & 14.68 \\
\hline 15 & Jorhat-2 & 12.50 & 13.25 & 15.80 \\
\hline 16 & Bidar-2 & 10.00 & 11.00 & 12.88 \\
\hline & S.Em \pm & 1.11 & 0.78 & 0.72 \\
\hline & CD $(\mathbf{0 . 0 5})$ & 3.34 & 2.35 & 2.17 \\
\hline & CV $(\%)$ & 12.08 & 7.39 & 5.94 \\
\hline
\end{tabular}

\section{Acknowledgement}

The authors are thankful to Dr. N. Basavaraj, Dean College of Horticulture Sirsi for facilities and Dr. Ramangoud H., Asst. Prof. College of Horticulture, Bagalkot, UHS Bagalkot for the technical support.

\section{References}

Anonymous, 2013, Improved Cultivation Practices for Horticultural Crops (Karnataka). Univ. Hort. Sci., Bagalkot. Pp. 89-91. 
Anonymous, 2017, Indian Horticulture Database, National Horticulture Board, 2016-2017. Ministry of Agriculture, Government of India, Gurgaon, P. 14.

Bhumanavar, B. S., Singh, S. P. and Sulladmath, V. V., 1989, Evaluation of citrus germplasm for resistance to the black aphid, Toxoptera auranlii (Boy) under tropical humid South Indian conditions. Insect Sci. Appl., to: 81-88.

Devasahayam, S. and Koya, K.M.A., 2004, Insect pests of ginger. In: Ginger, The Genus Zingiber (Eds. PN Ravindran. KN Babu), CRC Press, Washington, pp. 367-389.

Devasahayam, S., Jacob, T. K., Koya, A. K. M. and Sasikumar, B., 2010, Screening of ginger (Zingibe rofficinale) germplasm for resistance to shoot borer (Conogethes punctiferalis Guen.). J.
Medicinal \& Aromatic Plant Sci., 32(2): 137-138.

Koya, K.M.A., Balakrishnan, R., Devasahayam, S. and Banerjee, S. K., 1986, A sequential sampling strategy for the control of shoot borer (Dichrocrocis punctiferafis Guen.) in ginger (Zingiber officinale Rosc.) in India. Trop. Pest Management, 32: 343346.

Koya, K.M.A., Premkumar, T. and Gautam, S.S.S., 1988. Chemical control of shoot borer (Dichocrocis punctiferalis Guen.) on ginger (Zingiher officinale Rose.) $\mathrm{J}$. PI Crops, 16: 58-59.

Senapati, and Ghose, S., 2005, Screening of ginger varieties against rhizome rot disease complex in eastern ghat high land zone of Orissa. Indian Phytopath. 58(4): 437-439.

\section{How to cite this article:}

Ravi, Y., V.B. Narayanpur, J. Jayappa, A. Prashant, G.R. Santosha, P.S. Mahantesh, N.M. Kotur and Avinash, M. 2018. Screening of Ginger Genotypes for Shoot Borer (Conogethes punctiferalis Guen.) Resistance under Soppinabetta Ecosystem of Karnataka, India. Int.J.Curr.Microbiol.App.Sci. 7(05): 1402-1405. doi: https://doi.org/10.20546/ijcmas.2018.705.166 